African Crop Science Journal by African Crop Science Society is licensed under a Creative Commons Attribution 3.0 Uganda License. Based on a work at www.ajol.info/ and www.bioline.org.br/cs DOI: http://dx.doi.org/10.4314/acsj.v26i1.6

\title{
EVALUATION OF MICROBIAL AND ENZYMATIC COMMUNITIES IN SOIL AND RIZOSPHERE FROM SOYBEAN PLANTS
}

\author{
M.S. SANTOS, E.S.D. VILLELA ${ }^{1}$, R.A.A. PAZIANOTTO ${ }^{2}$, E.F. REYNALDO ${ }^{3}$, E.H.F.M. SILVA ${ }^{4}$, \\ A.C.S.O. BUENO ${ }^{5}$ and A. MAY ${ }^{6}$
}

Laboratory of Environmental Microbiology, Brazilian Agricultural Research Corporation, EMBRAPA Environment, SP 340, Km 127.5, 13820-000, Jaguariúna, SP, Brazil

${ }^{1}$ Laboratory of Organic Extracts, Brazilian Agricultural Research Corporation, EMBRAPA Environment, SP 340, Km 127.5, 13820-000, Jaguariúna, SP, Brazil

${ }^{2}$ Brazilian Agricultural Research Corporation, EMBRAPA Environment, SP 340, Km 127.5, 13820-000,

Jaguariúna, SP, Brazil

${ }^{3}$ Agronomic Engineer, Monsanto Company, Uberlândia e Região, Brazil

${ }^{4}$ University of São Paulo (USP), Luiz de Queiroz College of Agriculture (ESALQ), Piracicaba-SP, Brazil

${ }^{5}$ Federal Rural University of Amazônia (UFRA), Belém-PA, Brazil

${ }^{6}$ Brazilian Agricultural Research Corporation, EMBRAPA Environment, SP 340, Km 127.5, 13820-000, Jaguariúna, SP, Brazil

Corresponding author: michellisantos30@ hotmail.com

(Received 2 October, 2017; accepted 13 February, 2018)

\begin{abstract}
Understanding the biological and biochemical soil properties, as well as its enzymatic activity is important in designing an efficient alternative to demonstrate desired modifications in the soil. Such modifications are related to crop systems, cultivation practices or other human activities. The objective of this study was to evaluate the diversity of some microorganisms (Bacillus, Pseudomonas, Trichoderma and Fusarium) and enzymatic activity in soil from soybean crops with different yields. Soil sampling was determined according to the productivity yields of the property, which were divided into high, medium, and low yield. Microorganisms were evaluated by counting populations of fungi and bacteria through serial dilutions of total bacteria, Bacillus, Pseudomonas, Trichoderma and Fusarium. The $\beta$-glucosidase, acid phosphatase and arylsulphatase activities were determined by spectrophotometry after one hour of incubation at $37{ }^{\circ} \mathrm{C}$, with the specific substrate $\mathrm{p}$-nitrophenol- $\beta$-Dglucopyranoside, p-nitrophenol-phosphate and p-nitrophenyl sulphate, respectively, for each studied enzyme. Urease was determined by the ammonium release method, after incubating the soil with urea for two hours, at 37 ${ }^{\circ} \mathrm{C}$. Soil samples from the high-yield plot had higher concentrations of Bacillus and total bacteria. The low-yield soil showed a higher level of colonies of the genus Fusarium. The studied enzyme activities ( $\beta$-glycosidase, arylsulphatase and urea) were found at lower values in soil samples from the high-yield field and differed statistically from the low-yield field. However, in the rhizosphere samples, these enzymes had a higher activity in the high-yield field. In view of these results, it is possible that the yield of soybean plants influences the number of microorganisms and the enzymatic activity of the soil microbiota.
\end{abstract}

Key Words: Bacillus, p-nitrophenol- $\beta$-D-glucopyranoside, Pseudomonas, Trichoderma and Fusarium 
Comprendre les propriétés biologiques et biochimiques du sol, de même que son activité enzymatique est important dans la mise œuvre d'une alternative efficiente pour démontrer les modifications désirées dans le sol. De telles modifications sont reliées aux systèmes de culture, pratiques culturales ou les autres activités humaines. L'objectif de cette étude était d'évaluer la diversité de quelques microorganismes (Bacillus, Pseudomonas, Trichoderma and Fusarium) et activité enzymatique dans le sol des cultures du soja avec différents rendements. L'échantillonnage des sols était déterminé selon la productivité de la propriété, qui était divisée en élevée, moyenne et faible rendement. Les microorganismes étaient évalués par comptage des populations des champignons et bactéries à travers des séries de dilutions des bactéries totales, Bacillus, Pseudomonas, Trichoderma and Fusarium. Les activités du b-glucosidase, acide phosphatase et arylsulphatase étaient déterminées par la spectrophotométrie après une heure d'incubation à $37^{\circ} \mathrm{C}$, avec le substrat spécifique de p-nitrophenol-b-Dglucopyranoside, p-nitrophenol-phosphate et p-nitrophenyl sulphate, respectivement, pour chaque enzyme étudiée. Uréase était déterminée par la méthode de la libération d'ammonium, après incubation du sol avec l'urée pendant deux heures, à $37^{\circ} \mathrm{C}$. Les échantillons des terres à haut rendement ont les concentrations élevées en Bacillus et bactérie totale. Les terres à faible rendement ont montré un niveau élevé de colonies du genre Fusarium. Les activités des enzymes étudiées (b-glycosidase, arylsulphatase et urée) étaient trouvées à de faibles valeurs dans les échantillons de terres à haut rendement et diffèrent statistiquement des terres à faible rendement. Néanmoins, dans les échantillons de la rhizosphère, ces enzymes ont une activité élevée sur les terres à rendement élevé. D'après ces résultats, il est possible que le rendement des plants du soja influence le nombre de microorganismes et l'activité des enzymes des sols microbiote.

Mots Clés: Bacillus, p-nitrophenol-b-D-glucopyranoside, Pseudomonas, Trichoderma et Fusarium

\section{INTRODUCTION}

Understanding the biological and biochemical soil properties, as well as its enzymatic activity is important in designing an efficient alternative to demonstrate desired modifications in the soil. Such modifications are related to crop systems, cultivation practices or other human activities (Matsuoka et al., 2003). As stated by Gama-Rodrigues et al. (2005), soil organic matter has microbial biomass that is very sensitive to environmental and biological changes. According to these authors, responses to variations in the soil cultivation and management system can be detected much faster by analysing microbial biomass and its activity than variations in $\mathrm{C}$ and $\mathrm{N}$ levels in the soil. Siqueira et al. (1994) suggested that soil fertility is not subject only to the physical and chemical properties of the soil, but is also related to the activity and biological interactions taking place in the soil.

The soil consists of various chemical, physical and biological characteristics such as soil organic matter (SOM), water retention capacity, resistance to erosion, nutrient availability, microbial activity, cation exchange capacity, gas emission and organic $\mathrm{C}$, that can be measured to detect its modifications. However, the chosen bioindicators must be measurable, equivalent to these characteristics and enable the analysis and monitoring of changes that occur in this environment (Araújo et al., 2013).

The soil microbial activity indicates its quality and can be measured by the microbial C (Silva et al., 2010) and microbial N (GamaRodrigues et al., 2005). This activity may be also be evaluated by enzymatic reactions, e.g., $\beta$-glycosidase, urease, acid phosphatase and arylsulphatase; by the respiratory activity and microbial biomass of the soil (Lisboa et al., 2012); or by the most probable number (MPN) of bacteria and fungi in soil (Silveira et al., 2006).

The estimate of some microbial groups can probably indicate how biochemical actions are taking place in the soil. This is because the nutrient cycles in the soil are directly dependent on the microbial action (Silveira et al., 2006). The quantification of enzymes has become an effective soil bioindicator, since enzymatic 
activity can be used to evaluate the activity of the microbiota. In this regard, the most studied enzymes are $\beta$-glycosidase, arylsulphatase, acid phosphatase and urease (Araújo and Monteiro, 2007). The $\beta$-glycosidase enzyme hydrolyses the residues of cellobiose, acting in the final process of the cellulose decomposition (Eivazi and Tabatabai, 1988); therefore, changes in the activity of this enzyme can indicate the soil quality.

Passos et al. (2008) observed that the $\beta$ glycosidase activity in soil covered for up to 30 days, was higher in non-solarised compared with solarised soil, and that soil with addition of poultry litter showed a $5 \%$ increase in $\beta$ glycosidase activity.

Arylsulphatase is another enzyme that has been extensively examined in studies on soil quality. This enzyme releases sulphate ions into the soil solution from the hydrolysation of sulphate ester bonds, which are the substrate of the enzyme; thus participating in the sulphur cycle. This enzyme is released by microorganisms and vegetables through exudates of the root system or after death and disruption of root cells (Tabatabai and Bremer, 1970). According to Baligar et al. (1988), the arylsulphatase enzyme activity in the soil decreases with a reduction in the amount of organic matter and an increase in soil depth. Pinto and Nahas (2002) asserted that the arylsulphatase enzyme activity in integrated forest soil (integration between agriculture, livestock activities and forest plantation) was significantly higher compared with that of other studied soils (isolated forest, eucalyptus plantation, pasture and corn crop). The same authors observed that soil cultivated with corn had very low enzymatic activity $(0.15 \mu \mathrm{g}$ pnitrophenol $\mathrm{g}^{-1}$ soil $\mathrm{dm} \mathrm{h}^{-1}$ ), which was 152 times lower than the maximum found in integrated forest soil (37.02 $\mu \mathrm{g}$ p-nitrophenol $\mathrm{g}^{-1}$ soil $\mathrm{dm} \mathrm{h}^{-1}$ ).

Acid and alkaline phosphatase enzymes are also good indicators of the soil quality, as they are synthesised by microorganisms that mineralise the organic phosphorus in the soil, making it available to plants. Plants and microorganisms can excrete these enzymes, but most of them are produced by the former, because of their rapid metabolism (Dick and Tabatabai, 1992). Gatiboni et al. (2008) demonstrated that a lower availability of phosphorus in the soil can cause a decrease in the phosphorus content stored in the soil microbial biomass and an increase in the activity of acid phosphatase enzymes.

Urease, another important enzyme indicator for the soil quality, participates in the mineralisation of nitrogen, one of the main nutrients required by plants. This is an extracellular enzyme synthesised by bacteria, fungi and actinomycetes of the soil. It carries out hydrolysis of urea into carbon dioxide and ammonia, and the latter may have nitrogen immobilised by microorganisms and/or absorbed by plants (Tabatabai and Bremner, 1972). As reported by Vargas et al. (2005), urease activity is higher in the no-tillage system, compared with the conventional system, due to the accumulation of organic matter over time. The urease enzyme activity in plantations with crop residues was approximately 30 times higher than that observed in conventionally cultivated soils, and these, when compared with soils under the no-tillage system, showed a four times lower urease enzyme activity (Barreto and Westerman, 1989).

The objective of this study was to evaluate the diversity of some microorganisms and the â-glycosidase, arylsulphatase, phosphatase and urease enzymes in different soybean growing areas in state of Parana, Brazil

\section{MATERIALS AND METHODS}

This study was based on soil samples from soybean production areas collected at a property in Candói, Paraná State, Brazil (Table 1).

Soil sampling was determined according to the yield of the stands, as follows: $5.2 \mathrm{Mt}$ ha $^{-1}$, high yield; $4.2 \mathrm{Mt} \mathrm{ha}^{-1}$, medium yield; and 3.5 $\mathrm{Mt} \mathrm{ha}^{-1}$, low yield, represented by yield 
TABLE 1. Sampling site (Paraná State (PR)) features in Brazil

\begin{tabular}{lll}
\hline Sampling site & & Paraná \\
\hline City & & Candói \\
Coordinate & & S-25 $31^{\prime} 15,6^{\prime}, \mathrm{W}^{\circ} 51^{\circ} 47^{\prime} 19,8^{\prime \prime}$ \\
Climate features & Type & Cfb - Rainy during winter and summer \\
& Average annual temperature & $16.9^{\circ} \mathrm{C}$ \\
& Dry season & June to august \\
& Rainy season & September to February \\
& Monthly precipitation & 150 to 190 mm \\
Soil features & Type & Cambic aluminum Bruno Latosol \\
& Texture & Clay \\
Soil management & Planting system & Crop rotation: soybean, oat, maize, wheat, barley \\
Sampling & Soil type & Bulk soil and rhizosphere \\
\hline
\end{tabular}

Adapted from Santos et al. (2017)

maps measured by the properties' management system.

Sampling was achieved by collecting 10 subsamples or simple samples in each studied field aiming at the formation of a composite soil sample, harvested in a zigzag pattern. In total, 90 simple samples were collected in all areas. The same procedure was performed three times to compose the replicates (3) of the sampling in each plot with a different productivity history, but varying the initial point of entry of the plot for the collection of subsamples, considering another side of the same plot. The soil samples from the soybean inter-rows were collected with a Dutch soil auger.

Rhizospheric soil samples were composed of fractions of the rhizospheric soil collected from 20 soybean plants in each replicate, three replicates per productivity plot, which was established for the sampling of inter-rows in the studied plots. For this, the soybean plants at the stage of grain maturation were removed from the soil with the roots, and the soil adhered to them was reserved to form the composite sample (sample of soil from the rhizosphere or rhizospheric soil).
Soon after the removal of soil and rhizospheric soil simple samples, the composite samples of each treatment were placed in labelled plastic bags, packaged in a Styrofoam box and immediately sent to Embrapa's Environmental Microbiology Laboratory, located in Jaguariúna (SP, Brazil).

Procedures for soil analysis. In the laboratory, the samples were separated into three parts: (a) one for the evaluation of the microorganisms present in the soil; (b) another for the determination of $\beta$-glycosidase, acid phosphatase, urease and arylsulphatase enzymes; (c) and a third part was sent to the Soil Laboratory of Embrapa Maize and Sorghum, Sete Lagoas, MG, Brazil to analyse soil fertility by determination of macro and micronutrients, as well as $\mathrm{Al}$ and $\mathrm{pH}$.. Samples for the isolation of the cultivable microorganisms were stored at room temperature. For the enzyme determination, samples were ground through a $2 \mathrm{~mm}$ mesh sieve and stored at a temperature of $4{ }^{\circ} \mathrm{C}$.

Evaluation of microorganisms. The fungal and bacterial populations were counted through 
serial dilutions of total bacteria, Bacillus, Pseudomonas, Trichoderma and Fusarium (Costamilan, 2003; Fontes et al., 2003; Gomes et al., 2003; Silva et al., 2007; Silva et al., 2011a).

Enzymatic analyses. The $\beta$-glycosidase (Tabatabai, 1982; Eivazi and Tabatabai, 1988), acid phosphatase (Tabatabai and Bremner, 1969; Eivazi and Tabatabai, 1977) and arylsulphatase (Tabatabai and Bremmer, 1970) enzyme activities were determined by spectrophotometry after an hour of incubation at $37{ }^{\circ} \mathrm{C}$, with the specific substrate $\mathrm{p}$ nitrophenol- $\beta$-D-glucopyranoside, $p$ nitrophenol-phosphate and p-nitrophenyl sulphate, respectively for each enzyme. After the preparation of a standard curve of $\mathrm{p}$ nitriphenol, we obtained the activities in $\mu \mathrm{g} p$ nitrophenol $\mathrm{g}^{-1}$ soil $\mathrm{dm} \mathrm{h}^{-1}$.

Urea was determined by the method of Tabatabai and Bremner (1972), which is based on the determination of the ammonium released after incubation of the soil with urea for two hours at $37{ }^{\circ} \mathrm{C}$. The produced ammonia was measured by distillation and titration (Tedesco, 1985) and expressed in ìg ammonia $\mathrm{g}^{-1}$ soil $\mathrm{dm} \mathrm{h}^{-1}$.

For the statistical analysis, the values observed for the microorganisms were subjected to an analysis of variance performed in the SISVAR software, whereas the enzymes values were analysed using in the $\mathrm{R}$ software. When the treatments differed significantly by the F test, means were compared by the Tukey test at the $5 \%$ probability level.

\section{RESULTS}

Microorganisms. There were significant differences for the genera Bacillus, Trichoderma and Fusarium and for the total bacteria in the soil (Table 2). The test of means revealed that genus Bacillus presented the highest number of colonies in the medium- and low-yield soils (9.94 $10^{6} \mathrm{a}$ and $8.6710^{6} \mathrm{a} \mathrm{cfu}$ ) compared with the soil collected in the highyield field $\left(1.5810^{6} \mathrm{cfu}\right)$.

The number of colonies of genus Trichoderma was higher in the field with a history of medium yield $\left(28.8310^{6} \mathrm{cfu}\right)$ compared with the high- $\left(19.3310^{6} \mathrm{cfu}\right)$ and low-yield $\left(0.0810^{6} \mathrm{cfu}\right)$ soils. On the other hand, the colonies of genus Fusarium were found at higher values in the low-yield soil (9.08 $\left.10^{6} \mathrm{cfu}\right)$ compared with the high- and medium-yield soils, which, in turn, showed $2.7510^{6}$ and $2.4210^{6} \mathrm{cfu}$, respectively (Table 2).

There were significant differences for the genera Trichoderma and Fusarium in the soybean plant rhizospheric soil samples (Table 3 ). The test of means revealed that genus Trichoderma showed higher values of colonies in the samples of rhizospheric soil (155.33 10 $\mathrm{cfu}$ ) from the low-yield field, compared with the other rhizosphere samples from the highand medium-yield plots, with respective values

TABLE 2. Values for colony forming units in different soil samples from a farm in Paraná State in Brazil

\begin{tabular}{lrlccr}
\hline Yield & Bacteria total & Bacillus spp. & Pseudomonas spp. & Trichoderma spp. & Fusarium spp. \\
\hline High & $10.1710^{6 \mathrm{a}}$ & $1.5810^{6} \mathrm{~b}$ & $3.5810^{6} \mathrm{a}$ & $19.3310^{6} \mathrm{~b}$ & $2.7510^{3} \mathrm{~b}$ \\
Medium & $3.8310^{6} \mathrm{~b}$ & $9.9410^{6} \mathrm{a}$ & $3.3310^{6} \mathrm{a}$ & $28.83810^{6} \mathrm{a}$ & $2.4210^{3} \mathrm{~b}$ \\
Low & $2.5010^{6} \mathrm{~b}$ & $8.6710^{6} \mathrm{a}$ & $4.5810^{6} \mathrm{a}$ & $0.0810^{6} \mathrm{c}$ & $9.0810^{3} \mathrm{a}$ \\
& & & & & \\
LSD $(0.05)$ & 11.17 & 14.48 & 3.15 & 23.08 & 3.43 \\
CV $(\%)$ & 27.36 & 39.37 & 36.40 & 29.95 \\
\hline
\end{tabular}

Means followed by same letter do not differ by Tukey's test at $5 \%$ probability 
TABLE 3. Values for colony-forming units (cfu) in the different rhizospheric soil samples from Paraná State in Brazil

\begin{tabular}{lccccc}
\hline Yield & Bacteria total & Bacillus spp. & Pseudomonas spp. & Trichoderma spp. & Fusarium spp. \\
\hline High & $25.9210^{6 \mathrm{a}}$ & $110.2510^{6} \mathrm{a}$ & $3.2510^{6} \mathrm{a}$ & $24.1710^{6} \mathrm{~b}$ & $6.0010^{3} \mathrm{~b}$ \\
Medium & $22.9210^{6 \mathrm{a}}$ & $108.5810^{6} \mathrm{a}$ & $1.9410^{6} \mathrm{a}$ & $14.6710^{6} \mathrm{c}$ & $10.7510^{3 \mathrm{a}}$ \\
Low & $26.0010^{6 \mathrm{a}}$ & $109.7510^{6} \mathrm{a}$ & $2.2510^{6} \mathrm{a}$ & $155.3310^{6} \mathrm{a}$ & $11.3310^{3 \mathrm{a}}$ \\
& & & & & \\
LSD (0.05) & 13.65 & 45.95 & 2.95 & 9.17 & 1.73 \\
CV $(\%)$ & 27.55 & 19.96 & 26.43 & 7.18 & 7.86 \\
\hline
\end{tabular}

Means followed by the same letter do not differ by Tukey's test at $5 \%$ probability

of $24.1710^{6}$ and $14.6710^{6} \mathrm{cfu}$. The rhizosphere samples also presented higher numbers for Fusarium colonies in the lowyield $\left(11.3310^{6} \mathrm{cfu}\right)$ compared with the highyield plot $\left(6.0010^{6} \mathrm{cfu}\right)$. Total bacteria and the genera Bacillus and Pseudomonas did not show statistical differences between the samples of rhizospheric soil from the different studied plots (Table 3).

Chemical enzymes and soil analysis. There were no significant differences for most of the chemical characteristics of soil and rhizosphere region at the different yields studied (Table 4). However, total enzymatic activity (Table 5) was statistically different across the studied yields. The soil that presented the best enzymatic characteristics for the $\beta$-glycosidase and arylsulphatase enzymes was that one collected from mediumyield plots. The high-yield field showed higher values for the acid phosphatase enzyme, whereas the low-yield field had the highest levels of the urease enzyme.

The principal component analysis (PCA) revealed a separation of the soil samples by the yield history of the plots (high, medium and low). Samples from the sites with a history of high and medium yields were distant by approximately $39.0 \%$; while samples from low- and medium-yield fields had a distance of around $18 \%$ (Fig. 1-A). The attributes that most influenced the separation of samples (correlation 1) positively were, in descending order, $\mathrm{SAT}>\mathrm{Al}>\mathrm{H}+\mathrm{Al}>\mathrm{C}>\mathrm{CEC}>$ Urease; and negatively, $\mathrm{pH}>\mathrm{Ca}>\mathrm{SB}>$ base saturation. (Fig. 1- C). Where SAT $=0.9975558, \mathrm{Al}=$ $0.9974971, \mathrm{H}+\mathrm{Al}=0.9965566, \mathrm{C}=$ $0.9790480, \mathrm{CEC}=0.9780503, \mathrm{Ca}=-$ 0.9873851 , and $\mathrm{SB}=-0.9874240$. In the separation of samples for correlation 2, the most influential factors were the arylsulphatase enzyme (-0.7904293) and manganese $(\mathrm{Mn})$ (0.7334711) (Fig. 1 - D).

The PCA showed that the samples were separated by the historical yield of the studied plots in the rhizospheric soil collected, with samples distant from each other by approximately $41 \%$ horizontally, and vertically by approximately $20 \%$ (Fig. 2-A). These differences can be better visualised by the correlation between the studied attributes and the different yields, since it shows which attributes had the most influence on the differentiation of the samples. Overall, in the comparison of samples by yield history, the factors that most contributed positively to the horizontal dissimilarity of the rhizospheric soil were the chemical attributes $\mathrm{Mg}>\mathrm{CEC}>$ and phosphatase; and negatively, $\beta$-glycosidase (Fig. 2-C). Vertically, this differentiation was more influenced positively by urease and negatively by Mn (Fig. 2-D).

\section{DISCUSSION}

Microorganisms. Soil from the high-yield plot showed higher densities of Bacillus and total bacteria colonies (Table 2), suggesting a greater diversity of microorganisms in the study area. 
TABLE 4. Chemical characterisation of dry soil collected after soybean planting in areas with different yields in Brazil

\begin{tabular}{|c|c|c|c|c|c|c|c|c|}
\hline \multirow[t]{2}{*}{ Variable } & \multicolumn{4}{|c|}{ Rhizosphere } & \multicolumn{4}{|c|}{ Soil } \\
\hline & $\mathrm{H}-\mathrm{R}$ & M-R & L-R & $\mathrm{CV}(\%)$ & $\mathrm{H}-\mathrm{S}$ & M-S & L-S & $\mathrm{CV}(\%)$ \\
\hline $\mathrm{pH} \mathrm{H}_{2} \mathrm{O}$ & $6.7 \mathrm{a}$ & $6.7 \mathrm{a}$ & $6.6 \mathrm{a}$ & 2.2 & $6.2 \mathrm{a}$ & $6.2 \mathrm{a}$ & $6.2 \mathrm{a}$ & 2.2 \\
\hline Phosphorus Mehlich $\left(1 \mathrm{mg} \mathrm{dm}^{-3}\right)$ & $16.9 \mathrm{a}$ & $16.1 \mathrm{a}$ & $19.1 \mathrm{a}$ & 28.0 & $8.7 \mathrm{a}$ & $4.8 \mathrm{a}$ & $6.7 \mathrm{a}$ & 38.3 \\
\hline Nitrogen $\left(\mathrm{g} \mathrm{kg}^{-1}\right)$ & $79.6 \mathrm{a}$ & $73.8 \mathrm{a}$ & $67.5 \mathrm{a}$ & 8.6 & $64.6 \mathrm{a}$ & $61.7 \mathrm{a}$ & $54.3 \mathrm{a}$ & 7.0 \\
\hline Total carbon $\left(\mathrm{g} \mathrm{kg}^{-1}\right)$ & $46.3 \mathrm{a}$ & $42.9 \mathrm{a}$ & $41.9 \mathrm{a}$ & 7.3 & $37.6 \mathrm{a}$ & $35.9 \mathrm{a}$ & $35.0 \mathrm{a}$ & 6.3 \\
\hline $\mathrm{H}+\mathrm{Al}^{2+}\left(\mathrm{cmolc} \mathrm{dm}^{-3}\right)$ & $4.8 \mathrm{~b}$ & $5.5 \mathrm{ab}$ & $6.1 \mathrm{a}$ & 8.6 & $8.1 \mathrm{a}$ & $6.9 \mathrm{~b}$ & $7.4 \mathrm{ab}$ & 5.7 \\
\hline $\mathrm{Al}^{2+}\left(\mathrm{cmolc} \mathrm{dm}^{-3}\right)$ & $0.003 \mathrm{a}$ & $0.000 \mathrm{a}$ & $0.000 \mathrm{a}$ & 300.0 & $0.010 \mathrm{a}$ & $0.010 \mathrm{a}$ & $0.013 \mathrm{a}$ & 30.0 \\
\hline $\mathrm{Ca}^{2+}\left(\mathrm{cmolc} \mathrm{dm}^{-3}\right)$ & $7.2 \mathrm{a}$ & $6.4 \mathrm{a}$ & $6.8 \mathrm{a}$ & 7.0 & $4.9 \mathrm{a}$ & $4.3 \mathrm{a}$ & $4.6 \mathrm{a}$ & 7.6 \\
\hline $\mathrm{Mg}^{2+}\left(\mathrm{cmolc} \mathrm{dm}^{-3}\right)$ & $2.5 \mathrm{a}$ & $1.8 \mathrm{~b}$ & $2.0 \mathrm{~b}$ & 7.9 & $1.4 \mathrm{a}$ & $1.3 \mathrm{a}$ & $1.2 \mathrm{a}$ & 6.8 \\
\hline $\mathrm{K}^{+}\left(\mathrm{mg} \mathrm{dm}{ }^{-3}\right)$ & $259.6 \mathrm{a}$ & $220.1 \mathrm{a}$ & $236.9 \mathrm{a}$ & 7.1 & $181.7 \mathrm{a}$ & $122.5 \mathrm{a}$ & $164.3 \mathrm{a}$ & 19.0 \\
\hline $\mathrm{SB}\left(\mathrm{cmolc} \mathrm{dm}^{-3}\right)$ & $9.4 \mathrm{a}$ & $9.0 \mathrm{a}$ & $9.6 \mathrm{a}$ & 7.1 & $6.7 \mathrm{a}$ & $6.4 \mathrm{a}$ & $6.8 \mathrm{a}$ & 7.1 \\
\hline CEC $\left(\mathrm{cmolc} \mathrm{dm}^{-3}\right)$ & $15.7 \mathrm{a}$ & $13.9 \mathrm{~b}$ & $14.9 \mathrm{ab}$ & 3.2 & $15.3 \mathrm{a}$ & $13.3 \mathrm{~b}$ & $14.2 \mathrm{ab}$ & 4.8 \\
\hline Base saturation (\%) & $67.7 \mathrm{a}$ & $62.5 \mathrm{a}$ & $62.6 \mathrm{a}$ & 4.6 & $47.8 \mathrm{a}$ & $48.0 \mathrm{a}$ & $46.2 \mathrm{a}$ & 5.9 \\
\hline Al sat. $(\%)$ & $0.003 \mathrm{a}$ & $0.000 \mathrm{a}$ & $0.000 \mathrm{a}$ & 300.0 & $0.1 \mathrm{a}$ & $0.2 \mathrm{a}$ & $0.2 \mathrm{a}$ & 32.0 \\
\hline $\mathrm{Cu}^{2+}\left(\mathrm{mg} \mathrm{dm}^{-3}\right)$ & $2.1 \mathrm{a}$ & $1.8 \mathrm{a}$ & $1.7 \mathrm{a}$ & 31.6 & $4.2 \mathrm{a}$ & $2.8 \mathrm{ab}$ & $2.2 \mathrm{~b}$ & 21.0 \\
\hline $\mathrm{Fe}^{2+}\left(\mathrm{mg} \mathrm{dm}^{-3}\right)$ & $26.4 \mathrm{~b}$ & $25.0 \mathrm{~b}$ & $35.9 \mathrm{a}$ & 11.8 & $38.0 \mathrm{a}$ & $46.7 \mathrm{a}$ & $42.7 \mathrm{a}$ & 14.0 \\
\hline $\mathrm{Mn}^{2+}\left(\mathrm{mg} \mathrm{dm}^{-3}\right)$ & $26.4 \mathrm{a}$ & $22.5 \mathrm{a}$ & $15.3 \mathrm{~b}$ & 9.3 & $16.1 \mathrm{a}$ & $11.0 \mathrm{a}$ & $11.1 \mathrm{a}$ & 18.5 \\
\hline $\mathrm{Zn}^{2+}\left(\mathrm{mg} \mathrm{dm}^{-3}\right)$ & $6.4 \mathrm{a}$ & $5.0 \mathrm{a}$ & $6.0 \mathrm{a}$ & 17.4 & $9.9 \mathrm{a}$ & $5.8 \mathrm{a}$ & $7.1 \mathrm{a}$ & 42.3 \\
\hline
\end{tabular}

Means followed by the same letter in the row do not differ, for each collection, by Tukey's test $(\mathrm{P}<0.05)$ performed using the Rstudio statistical software. High rhizosphere yield (H-R), Medium rhizosphere yield (M-R), Low rhizosphere yield (L-R), High soil yield (H-S), Medium soil yield (M-S), Low soil yield (L-S) 
M.S. SANTOS et al.

Microorganisms are important in organic matter degradation and soil nutrient dynamics, mediating plant development. Genus Bacillus can influence seeds germination and plant growth promotion (Schisler et al., 2004). According to Araújo and Hungria (1999), the $B$. subtilis isolate or its metabolites increase nodulation and yield in soybean. It is widely reported that soils showing greater biodiversity have more classes of microorganisms that operate in the degradation processes of agricultural pesticides and conservation of microbiological processes in situations of environmental stress. This is generally referred to as "biological buffering effect" (Pereira $e t$ al., 2007).

The low-yield soil showed a higher number of colonies of genus Fusarium (Table 2). Some species of this genus are pathogenic to soybean, e.g. Fusarium semiquumum (Goulart, 2004), Fusarium graminearum (Ellis et al., 2011), and Fusarium solani (Mart.) Sacc. f. sp. glycines (Roy, 1997). Thus, the presence of a higher quantity of this fungus in the soil from the low-yield plots can be considered an important bioindicator for the decrease in the yield of these cultivated areas.

Trichoderma is a genus well-known for promoting plant growth, which may explain the higher number of cfu in the soil collected from the plot with a medium historical yield. According to Silva et al. (2011), substrate inoculated with Trichoderma species increase growth of cucumber plants by $100 \%$. In addition, many species of Trichoderma spp. have been used in the biocontrol of pathogens, such as Venturia spp. and Botrytis spp. (Mello, 1996). In the rhizosphere samples from the low-yield plot, there was a high number of cfu of genus Trichoderma. Although this genus is known as a promoter of plant growth and a pathogen inhibitor, the high number of colonies of this genus may be causing a microbial imbalance near the roots of soybean plants (Vinale et al., 2008). The high number of Trichoderma colonies may have caused a microbial imbalance near the roots of the soybean plants. This imbalance may be related 


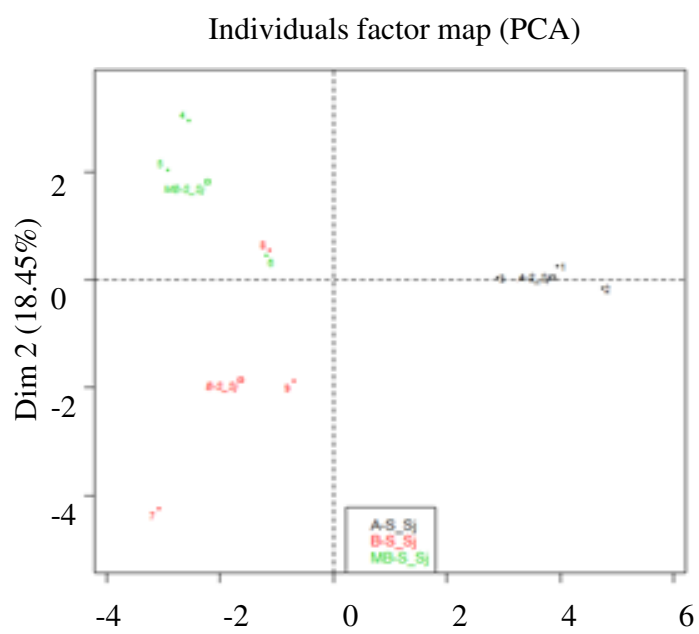

Dim 1 (39.39\%)
B

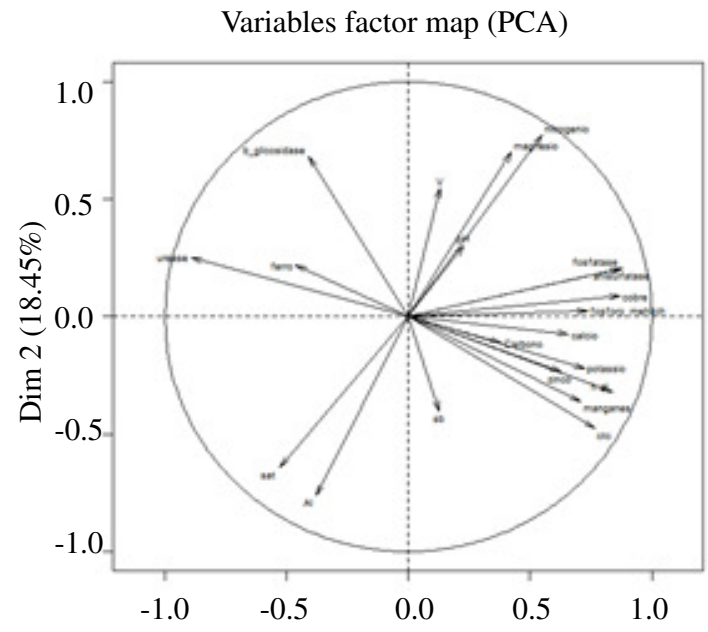

Dim 1 (39.39\%)

\begin{tabular}{|c|c|c|c|c|c|}
\hline \multicolumn{6}{|l|}{$\mathrm{C}$} \\
\hline Analysis & Correlation (soil) & P. value & Analysis & Correlation (soil) & P. value \\
\hline SAT & 0.9975558 & $6.841424 \mathrm{e}-13$ & $\mathrm{P}$ & -0.6136250 & $3.381967 \mathrm{e}-02$ \\
\hline $\mathrm{Al}$ & 0.9974971 & $7.702451 \mathrm{e}-13$ & $\mathrm{Zn}$ & -0.6889806 & $1.320568 \mathrm{e}-02$ \\
\hline $\mathrm{H}+\mathrm{Al}$ & 0.9965566 & $3.790453 \mathrm{e}-12$ & $\beta$-glycosidase & -0.7328988 & $6.696557 \mathrm{e}-03$ \\
\hline Carbon & 0.9790480 & $3.070088 \mathrm{e}-08$ & $\mathrm{~K}$ & -0.9366100 & $7.242827 \mathrm{e}-06$ \\
\hline CEC & 0.9780503 & $3.867535 \mathrm{e}-08$ & $\mathrm{Mg}$ & -0.9474775 & $2.881227 \mathrm{e}-06$ \\
\hline Urease & 0.9777082 & $4.176104 \mathrm{e}-08$ & $\mathrm{pH}$ & -0.9828953 & $1.120489 \mathrm{e}-08$ \\
\hline Nitrogen & 0.9655222 & $3.620973 \mathrm{e}-07$ & $\mathrm{Ca}$ & -0.9873851 & $2.463312 \mathrm{e}-09$ \\
\hline Phosphatase & 0.9209508 & $2.126387 \mathrm{e}-05$ & SB & -0.9874240 & $2.425718 \mathrm{e}-09$ \\
\hline $\mathrm{Fe}$ & 0.9121955 & $3.541559 \mathrm{e}-05$ & Base saturation & -0.9943791 & 4.377131e-11 \\
\hline \multicolumn{6}{|l|}{ D } \\
\hline & Analysis & \multicolumn{2}{|c|}{$\begin{array}{c}\text { Correlation } \\
\text { (rhizospheric soil) }\end{array}$} & P. value & \\
\hline & Manganese & \multicolumn{2}{|c|}{0.7334711} & 0.006632152 & \\
\hline & \multirow{2}{*}{$\begin{array}{l}\text { Copper } \\
\beta \text {-glycosidase }\end{array}$} & \multirow{2}{*}{\multicolumn{2}{|c|}{0.6403975}} & 0.024873676 & \\
\hline & & & & 0.097391479 & \\
\hline & Arylsulfatase & \multicolumn{2}{|c|}{$\begin{array}{l}-0.5005957 \\
-0.7904293\end{array}$} & 212409 & \\
\hline & Analysis & \multicolumn{2}{|c|}{$\begin{array}{c}\text { Correlation } \\
\text { (rhizospheric soil) }\end{array}$} & P. value & \\
\hline & $\mathrm{Mn}$ & \multicolumn{2}{|c|}{0.7334711} & 0.006632152 & \\
\hline & $\mathrm{Cu}$ & \multicolumn{2}{|c|}{0.6403975} & 0.024873676 & \\
\hline & \multirow{2}{*}{$\begin{array}{l}\beta \text {-glycosidase } \\
\text { Arylsulfatase }\end{array}$} & \multicolumn{2}{|c|}{-0.5005957} & 0.097391479 & \\
\hline & & \multicolumn{2}{|c|}{-0.7904293} & 0.002212409 & \\
\hline
\end{tabular}

Figure 1. Principal Component Analysis for specific enzymatic activity and chemical attributes of soil collected from a soybean crop in areas with different yields. A - Graph of individual factor PCA. B - Map of several PCA factors. C- Correlation 1 - horizontal distance between samples. D - Correlation 2 - vertical distance between samples. 
A

Individuals factor map (PCA)

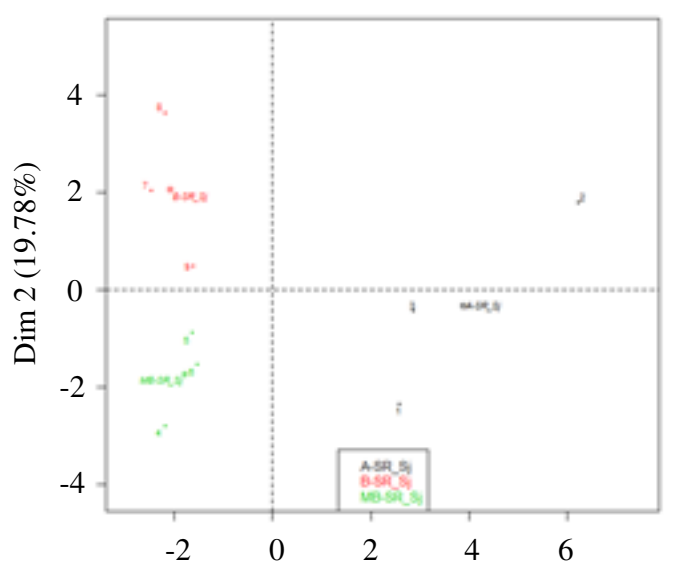

$\operatorname{Dim} 1(40.76 \%)$
B

Variables factor map (PCA)

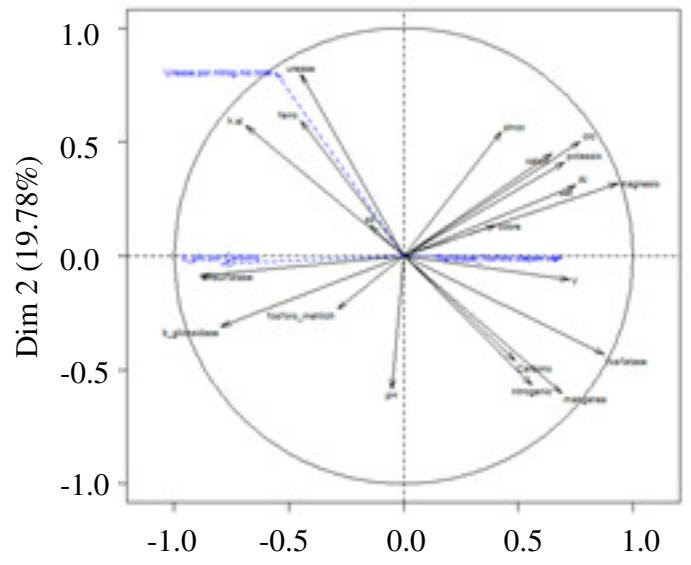

$\operatorname{Dim} 1(40.76 \%)$

\begin{tabular}{|c|c|c|c|c|c|}
\hline \multicolumn{6}{|l|}{$\mathrm{C}$} \\
\hline Analysis & $\begin{array}{c}\text { Correlation } \\
\text { Rhizosphere) }\end{array}$ & P. value & Analysis & $\begin{array}{l}\text { Correlation } \\
\text { (Rhizosphere) }\end{array}$ & P. value \\
\hline $\mathrm{Mg}$ & 0.93249 & 0.00025 & Phosphatase $/ \mathrm{P}_{\text {avail }}$ & 0.68997 & 0.0397 \\
\hline Phosphatase & 0.87329 & 0.0021 & $\mathrm{Mn}$ & 0.68856 & 0.04027 \\
\hline CEC & 0.77045 & 0.01512 & $\mathrm{Ca}$ & 0.64873 & 0.05873 \\
\hline $\mathrm{Al}$ & 0.75204 & 0.01942 & $\mathrm{H}+\mathrm{Al}$ & -0.6859 & 0.04139 \\
\hline Sat & 0.75204 & 0.01942 & b-glycosidase & -0.7953 & 0.0104 \\
\hline Base saturation & 0.72387 & 0.02746 & b-glyc/C $\mathrm{C}_{\text {avail, }}$ & -0.7953 & 0.0104 \\
\hline $\mathrm{K}$ & 0.70086 & 0.03544 & Arylsulfatase & -0.8887 & 0.00136 \\
\hline \multicolumn{6}{|l|}{$\mathrm{D}$} \\
\hline Analysis & $\begin{array}{l}\text { Correlation } \\
\text { Rhizosphere) }\end{array}$ & P. value & Analysis & $\begin{array}{l}\text { Correlation } \\
\text { (Rhizosphere) }\end{array}$ & P. value \\
\hline Urease $/ \mathrm{N}_{\text {Total }}$ & 0.80546 & 0.00879 & $\mathrm{pH}$ & -0.5836 & 0.09898 \\
\hline Urease & 0.79729 & 0.01006 & $\mathrm{Mn}$ & -0.6036 & 0.08523 \\
\hline $\mathrm{Fe}$ & 0.59426 & 0.09151 & & & \\
\hline
\end{tabular}

Figure 2. Principal Component Analysis for specific enzymatic activity (dotted blue), chemical doses and biological attributes of soil collected from the soybean rhizosphere area, comparing between areas with different yields. A - Graph of individual factor PCA. B - Map of several PCA factors. C- Correlation 1 - horizontal distance between samples. D - Correlation 2 - vertical distance between samples. 
to the production of secondary, volatile and non-volatile metabolites, which have a broad spectrum of antimicrobial action (Vinale et al., 2008).

The productivity of plants is linked to the microbiota of the environment, because microbial actions such as biological nitrogen fixation, mycorrhizae and solubilisation of minerals such as phosphate provide nutrients in the largest quantity for plants (Moreira and Siqueira, 2006). Thus, from a microbiological perspective, the occurrence of a more abundant environment can demonstrate its influence in the productivity of soybean plants.

Enzymes and nutrients. In addition to the microorganisms studied, the soil chemistry, bglucosity, acid phosphatase, arylsulfatase and urease enzymes were also evaluated to verify soil differences in the rhizosphere and in soil between plants, from plots cultivated with soybean with different productivity in the state of Paraná.

The chemical analysis of the soil for most of the attributes did not reveal differences between the studied soils, so we can infer that the yield difference between the plots. This possibly can be due to microbial diversity, its relationships with plants and their activities in the soil (Table 4).

For the specific $\beta$-glycosidase, arylsulphatase and urease enzymatic activities, soil from the high-yield soybean plot showed values statistically lower or equal to those obtained from the medium-yield plot (Table 5). However, in the rhizosphere samples, the enzymes had a greater activity in the high-yield field. The values found for these enzymes were lower in the soil collected from the low-yield soybean fields, likely because of the lower microbial activity of these cultivation environments, which, in turn, are able to release these enzymes.

Fernandes et al. (1998) reported that the activity of the acid phosphatase enzyme in two types of soil and three conditions of use (plant cultivation, rainforest and pasture) was lower in Oxisols with plant cultivation $(385 \mathrm{~mol} \mathrm{p}$ nitrophenol $\mathrm{g}^{-1} \mathrm{~h}^{-1}$ ) in a conventional system and in native-forest soil $(650 \mathrm{~mol}$ of $\mathrm{p}$ nitrophenol $\left.\mathrm{g}^{-1} \mathrm{~h}^{-1}\right)$. In the same soil, the organic phosphorus content of the microbial biomass was also lower under plant-growing conditions $\left(9 \mathrm{mg} \mathrm{kg} \mathrm{soil}^{-1}\right)$ than in the rainforest (15 mg kg soil ${ }^{-1}$ ). Thus, according to these authors, the higher acid phosphatase activity observed in soils under forest is possibly due to the higher immobilisation of $\mathrm{P}$ in the microbial biomass, reflecting the amount of microorganisms present in that soil. As stated by Conte et al. (2002), the microorganisms of soil cultivated in the no-tillage system have their importance in biocycling and $\mathrm{P}$ deposition in their cells. In this way, the phosphorus stays available for a longer time in the soil for absorption by the plants.

According to Nogueira and Melo (2003), the arylsulphatase enzyme activity is essential the plantation since this enzyme has the function of transforming organic forms of sulphur into inorganic forms, making them available to plants, and thus modifying their development. The results found for arylsulphatase activity in the fields with high yield history are, therefore, in agreement with the above concept, which determines that soils with a higher activity of this enzyme provide more-developed plants.

Mendes et al. (2003) evaluated the biological properties of an Oxisol under the no-tillage and conventional systems in the Brazilian cerrado biome that had been systematised for agriculture for 21 years. They reported that the area under conventional planting had significantly lower acid phosphatase and arylsulphatase values than the no-tillage soil. This finding reinforces the idea that soils with more organic residue have higher activities of the acid phosphatase and arylsulphatase enzymes.

In the rhizospheric soil, the $\beta$-glycosidase enzyme presented higher values in the samples from the medium-yield plot (Table 5). This enzyme participates in the final phase of 
the cellulose degeneration process by the hydrolysis of cellobiose residues, and changes in its activity can alter the soil quality (Passos et al., 2008). Thus, the higher values found in this study for this enzyme may indicate the microbial collapse that may be occurring near the rhizosphere of the plants. The carbon found in the soil was one of the factors that most influenced the yield differences studied, which can be explained by the activity of the $\beta$ glycosidase enzyme.

The PCA correlation (Fig. 1 - B) showed that an increase in urease activity is inversely proportional to the contents of $\mathrm{Ca}, \mathrm{Zn}, \mathrm{K}, \mathrm{C}$ and $\mathrm{Mn}$; this is because the complex nature of $\mathrm{N}$ in soil can lead to a lack of synchrony in availability of nutrients in the soil (Fontoura and Bayer, 2009).

A higher urease activity indicates a decrease in $\mathrm{N}$ content (Fig. 2-B), because this enzyme is responsible for the hydrolysis of urea. The volatilisation of ammonia is favoured by the higher urease activity that is usually observed in the topsoil of no-tillage fields (Barreto and Westerman, 1989).

The increase in acid phosphatase activity brought about by the increase in the soil magnesium content (Fig. 2-B) can be attributed to the activating effect of this cation on the activity of this enzyme (Nahas, 2002).

\section{CONCLUSION}

The number of microorganisms and the studied enzymatic activities in the soil under soybean crops vary according to the yield level of the plot.

\section{REFERENCES}

Araújo, F.F. and Hungria, M. 1999. Soybean nodulation and yield when co-inoculated with Bacillus subtilis and Bradyrhizobium japonicum/Bradyrhizobium elkanii. Pesquisa Agropecuária Brasileira, 34:1633-1643.
Araújo, A.S.F. and Monteiro, R.T.R. 2007. Indicadores biológicos de qualidade do solo. Bioscience Journal 23(3):66-75.

Araujo, F.F de. and Pedroso, R.A.B. 2013. Interaction of rhizobacteria Bacillus sp. with pastures rhizosphere. Bioscience Journal 29(1):152-158.

Araújo, A.S.F., Cesarz , S., Leite, L.F.C., Borges, C.D., Tsai, S.M., Eisenhauer, N. 2013. Soil microbial properties and temporal stability in degraded and restored lands of Northeast Brazil. Soil Biology \& Biochemistry 66:175-181.

Baligar, V.C., Wright, R.J., Smedley, M.D. 1988. Enzyme activities in hill land soils of the Appalachian region. Communications in Soil Science and Plant Analyses 19:367384.

Barreto, H.J. and Westerman, R.L. 1989. Soil urease activity in winter wheat residue management systems. Soil Science Society of American Journal 53:1455-1458.

Conte, E., Anghinoni, I., Rheinheimer, D.S. 2002. Fósforo Da Biomassa microbiana e atividade de fosfatase ácida após aplicação de fosfato em solo no sistema plantio direto. Revista Brasileira de Ciência do solo 26:925-930.

Costamilan, L.M. 2003. Recovery of colonies of Fusarium solani f. sp. glycines from soil and crop debris. Boletim de Pesquisa e desenvolvimento 12:1-16.

Dick, W.A. and Tabatabai, M.A. 1992. Significance and potential uses of soil enzymes. In: Metting Junior, F.B. (Ed.). Soil microbial ecology applications in agricultural and environmental management, New York: M. Dekker. pp. 95-127.

Eivazi F, Tabatabai MA. 1977. Phosphatases in soils. Soil Biology Biochemical 9:167177.

Eivazi, F. and Tabatabai, M.A. 1988. Glucosidases and galactosidase in soils. Soil Biology and Biochemistry 20(5):60-606.

Ellis, M.L., Broders, K.D., Paul, P.A. and Dorrance, A.E. 2011. Infection of soybean 
seed by Fusarium graminearum and effect of seed treatments on disease under controlled conditions. Plant disease 95(4):401-407.

Fernandes, A.R., Furtini Neto, A.E., Curi, N., Lima, J.M. and Guedes, G.A.A. 1998. Fósforo e atividade de fosfatase em dois solos sob diferentes condições de uso. Pesquisa Agropecuária Brasileira 33:11591170.

Fontes, C.L., Santos, F.S., Tavares, de.M.A. and Bovi, A.G. 2007. Interação de Bactérias Fluorescentes do Gênero Pseudomonas e de Bacillus spp. com a Rizosfera de Diferentes Plantas. Revista Brasileira de Ciência do Solo 31(6):1413-1420.

Fontoura, S.M.F. and Bayer, C. 2009. Nitrongen-fertilizer recommendation for high corn yields under no-tillage in the South-Central region of Paraná State, Brazil. Revista Brasileira de Ciência do Solo 33(6):1721-1732.

Gatiboni, L.C., Kaminski, J., Rheinheimer, D. Dos. S. and Brunetto, G. 2008. Soil microbial biomass phosphorus and activity of acid phosphatases during decline of soil available phosphorus. Pesquisa Agropecuária Brasileira 43(8):1085-1091.

Gama-Rodrigues, E.F., Barros, N.F., GamaRodrigues, A.C. and Santos, G.A. 2005. Carbon, nitrogen and activity of microbial biomass in soil under eucalypt plantations. Revista Brasileira de Ciência do Solo 9:893-901.

Goulart, A.C.P. 2005. Fungi in soybean seeds: Detection, importance and control. Embrapa Agropecuária Oeste, Dourados, MS, Br. 72pp.

Gomes, A.M.A., Mariano, R.L.R., Silveira, E.B. and Mesquita, J.C.P. 2003. Isolamento, seleção de bactérias e efeito da utilização de Bacillus spp. na produção de mudas orgânicas de alface. Horticultura Brasileira 21(4):699-703.

Lisboa, B.B., Vargas, L.K., Silveira, A.O., Martins, A.F. and Selbach, P.A. 2012. Microbial indicators of soil quality in different management systems. Revista brasileira de ciência do solo 36(1):33-44.

Nahas, E. 2002. Microrganismos do solo produtores de fosfatases em diferentes sistemas agrícolas. Bragantia 61(3):267275.

Matsuoka, M., Mendes, L.C. and Loureiro, M.F. 2003. Microbial biomass and enzyme activities in soils under native vegetation and under annual and perennial cropping systems at the primavera do leste region Mato Grosso state. Revista Brasileira de Ciência do Solo 7:425-433.

Mendes, I.C., Souza, L.V., Resck, D.V.S. and Gomes, A.C. 2003. Biological properties of aggregates from a cerrado oxisol under conventional and no-till management systems. Revista Brasileira de Ciência do Solo 27: 435-443.

Melarato, M., Panobianco, M., Vitti, G.C. and Vieira, R.D. 2002. Manganese and physiological quality of soybean seeds. Ciência Rural 32(6):1069-1071.

Mello, I.S. 1996. Trichoderma and Gliocladium as plant bioprotectors. Revisão Anual de Patologia de Plantas 4:261- 295.

Moreira, F.M.S. and Siqueira, J.O. 2006. Microbiologia e bioquímica do solo. UFLA, Lavras, MG, Br. 729pp.

Nogueira, M.A. and Melo, W.J. 2003. Enxofre disponível para a soja e atividade de arilsulfatase em solo tratado com gesso agrícola. Pesquisa Agropecuária Brasileira 27:655-663.

Pinto, C.R.O. and Nahas, E. 2002. Activity and microbial populations involved in sulfur cycling in soils with different vegetations. Pesquisa Agropecuária Brasileira 37(12):1751-1756.

Roy, K.W. 1997. Fusarium solani on soybean roots: nomenclature of the causal agent of sudden death syndrome and identity and relevance of $F$. solani form B. Plant Disease 81(3):259-266.

Santos, M. de. S. dos., Kavamura, V.N., Reynaldo, E.F., Souza, D.T., Da Silva, 
E.H.F.M. and May, A. 2017. Bacterial structure of agricultural soils with high and low yields. Journal of Plant Pathology \& Microbiology 8:405.

Schisler, D.A., Slininger, P.J., Behle, R.W. and Jackson, M.A. 2004. Formulation of Bacillus spp. for biological control of plant diseases. Phytopathology 94:12671271.

Silva, V.A. da, Dias, E.S., Vale, R.H.P. do, Silva, R. da and Moreira, G.F. 2007. Isolation and identification of bacteria present in the casing layer utilized to the cultivation of the mushroomAgaricus blazei Murril. Ciência e Agrotecnologia 31(5):1364-1373.

Silva, R.R.D., Silva, M.L.N., Cardoso, E.L., Moreira, F.M.D.S., Curi, N. and Alovisi, A.M.T. 2010. Soil biomass and microbial activity under different management systems in the physiographic region campos das vertentes - Minas Gerais. Revista Brasileira de Ciência do Solo, 34(5):1585-1592.

Silva, D.C.V. da, Tiago, P.V., Mattos, J.L.S. de, Paiva, L.M. and Souza-Motta, C.M. de. 2011 Isolation and screening of filamentous fungi from soil of agroforestry systems in the municipality of Bom Jardim (PE) for the ability to produce hydrolytic enzymes. Brazilian Journal of Botany 34(4):607-610.

Silva, V.N. Da, Guzzo, S.D., Lucon, C.M.M., Harakava, Ricardo. 2011. Growth promotion and resistance induction against anthracnose in cucumber using Trichoderma spp. Pesquisa agropecuária brasileira 46(12):1609-1618.

Siqueira, J.O, Moreira, F.M., Grisi, B.M., Hungria, M. and Araújo, R.S. 1994. Microrganismos e processos biológicos do solo: perspectiva ambiental. EMBRAPA, Brasília, Br. (EMBRAPA. Documento, 45). 142 pp.

Silveira, R.B., Melloni, R. and Melloni, E.G.P. 2006. Microbiologic and biochemical attributes as indicators of the recovery of degraded areas, in Itajubá/Mg. Cerne 12(1):48-55.

Passos, S.R., Reis Junior, F.B. dos., Rumjanek, N.G., Mendes, I. de. C., Baptista, M.J. and Xavier, G.R. 2008. Enzymatic activity and bacterial community profile in soil under solarization e biofumigation. Pesquisa Agropecuária Brasileira 43(7):879-885.

Pereira, A.A., Hungria, M., Franchini, J.C., Kaschuk, G., Oliveira Chueire, L.M.D., Campo, R.J. and Torres, E. 2007. Qualitative and quantitative changes in soil microbiota and biological nitrogen fixation under different soybean. Revista Brasileira de Ciência do Solo 31(6):1397-1412.

Tabatabai, M.A. and Bremner, J.M. 1969. Use of p-nitrophenol phosphate for the assay of soil phosphatase activity. Soil Biology Biochemistry 1:301-307.

Tabatabai, M.A. and Bremner, J.M. 1970. Arylsulfatase activity of soils. Soil Science Society of America 34:225-229.

Tabatabai, M.A. and Bremner, J.M. 1972. Assay of urease activity in soils. Soil Biology Biochemistry 4:479-487.

Tabatabai, M.A. 1982. Sulfur. pp. 501- 538. In: Page, R.L., Miller, R.H. and Keeney, D.R. (Eds.). Methods of soil analysis: Chemical and microbiological properties. 2.ed. Madison, USA.

Tedesco, M.J., Volkweiss, S.J. and Bohnen, H. 1985. Análises de solo, plantas e outros materiais. Faculdade de Agronomia, UFRGS. (Boletim Técnico, 5) Porto Alegre, Br. 174pp.

Vargas, L.K., Selbach, P.A. and De Sá, E.L.S. 2005. Nitrogen immobilization in soil cropped with maize in sequence to black oats in conventional and in no-till systems. Ciência Rural 35(1):76-83.

Vinale, F., Sivasithamparam, K., Ghisalberti. E.L., Marra, R., Sheridan L. Woo, S.L. and Lorito, M. 2008. Trichoderma-plantpathogen interactions. Soil Biology \& Biochemistry 40:1-10. 